\title{
Impact of Refrigeration on the Surface Hardness of Hybrid and Microfilled Composite Resins
}

\author{
Fernando Henrique Ruppel OSTERNACK ${ }^{1}$ \\ Danilo Biazzetto de Menezes CALDAS ${ }^{1}$ \\ Rodrigo Nunes RACHED ${ }^{1}$ \\ Sérgio VIEIRA ${ }^{1}$ \\ Jeffrey A. PLATT ${ }^{2}$ \\ Janaina Bertoncelo de ALMEIDA ${ }^{1}$
}

${ }^{1}$ Department of Restorative Dentistry, Pontifical Catholic University of Paraná, Curitiba, PR, Brazil
${ }^{2}$ Department of Restorative Dentistry, Indiana University School of Dentistry, Indianapolis, IN, USA

\begin{abstract}
This in vitro study evaluated the Knoop hardness of the composite resins Charisma ${ }^{\circledR}(\mathrm{C})$ and Durafill VS ${ }^{\circledR}$ (D) polymerized in 3 different conditions: at room temperature $\left({ }_{\mathrm{A}}\right)\left(23 \pm 1^{\circ} \mathrm{C}\right)$; refrigerated at $4 \pm 1{ }^{\circ} \mathrm{C}$ and immediately photo-activated after removal from the refrigerator $\left({ }_{0}\right)$; and, refrigerated at $4 \pm 1{ }^{\circ} \mathrm{C}$ and photo-activated after a bench time of 15 min at room temperature $\left({ }_{15}\right)$. One hundred and twenty specimens ( $4 \mathrm{~mm}$ diameter and $2 \mathrm{~mm}$ depth) were made using a stainless steel mold and following manufacturer's instructions. All specimens were tested immediately after polymerization $\left(_{\mathrm{I}}\right)$ and after 7 days of water storage in the dark at room temperature (7d). The data were subjected to ANOVA and post-hoc Tukey's test $(\alpha=0.05)$. On the top surface, $\mathrm{C}_{\mathrm{AI}}$ was statistically similar to $\mathrm{C}_{15 \mathrm{I}}$ and $\mathrm{D}_{\mathrm{AI}}$ to $\mathrm{D}_{15 \mathrm{I}}(\mathrm{p}>0.05)$. On the bottom surface, $\mathrm{C}_{\mathrm{AI}}$ presented higher hardness values when compared to $\mathrm{C}_{0 \mathrm{I}}$ and $\mathrm{C}_{15 \mathrm{I}}(\mathrm{p}<0.05)$. The $\mathrm{D}$ groups showed no significant differences $(\mathrm{p}>0.05)$ on the bottom surfaces for any tested polymerization condition. After 7 days of storage, the Knoop hardness decreased significantly $(\mathrm{p}<0.05)$ for groups $\mathrm{C}_{7 \mathrm{~d}}$ and $\mathrm{D}_{7 \mathrm{~d}}$ except for $\mathrm{C}_{07 \mathrm{~d}}$, which was not different from $\mathrm{C}_{0 \mathrm{I}}$ at either surface $(\mathrm{p}>0.05)$. $\mathrm{D}_{07 \mathrm{~d}}$ showed higher Knoop hardness $(\mathrm{p}<0.05)$ values on the top surface when compared to the other groups.
\end{abstract}

Key Words: resin composite, refrigeration, Knoop hardness.

\section{INTRODUCTION}

The curing of methacrylate-based composite resins for dental applications is a major issue due to its importance regarding biocompatibility (1), bacterial growth associated with the release of unreacted monomers (2) and improvement of the material's physical properties (3).

The balance of the components in the organic formulation has been proven essential during the polymerization process (4). Other factors controlling lightactivated polymerization are irradiance, wavelength (4), and the time needed for polymerization to occur $(5,6)$. Some studies have investigated the possibility that resin monomer flexibility and the temperature during polymerization may affect the conversion rate and the material properties (4).

Kloosterboer et al. (7) have shown that monomer mobility is higher with increased polymerization temperature. Trujillo et al. (8) have found that pre-heating the composite resin increases the immediate and the final conversion rates due to the increase of monomer mobility. Although relatively recent research has shown favorable results regarding the increase of the conversion rate with pre-heated composites (9), few studies have addressed the cooling of methacrylate resin materials $(9,10)$. This is an important issue to be investigated because the refrigerated storage of composite resins is a common practice to increase their shelf-life and is suggested by some manufacturers.

Monomers seem to need a certain mobility to be properly converted into polymers $(7,8)$. Since re-

Correspondence: Profa. Dra. Janaina Bertoncelo de Almeida, Departamento de Odontologia Restauradora, Pontifícia Universidade Católica do Paraná, PUCPR, Rua Imaculada Conceição, 1155, Prado Velho, 80215-901 Curitiba, PR, Brasil. Tel: +55-41-3271-2548. Fax: +55-41-3224-6688. e-mail: janainabertoncelo@hotmail.com 
frigeration could increase the material's viscosity (4), thereby decreasing monomer mobility, an alteration of the properties of the polymerized composite resin could be anticipated. It would be expected in cases where the material is used for a clinical procedure immediately after removal from refrigeration.

Knoop hardness test is directly related to the degree of conversion (11). Bouschlicher et al. (12), showed a linear correlation between hardness and degree of conversion when investigating the differences between the type of composite resin and the depth of cure of the specimen.

The purpose of this study was to determine the impact of refrigeration on the Knoop hardness of two restorative composite resins at the top and bottom surfaces of the specimens. The resins were polymerized in three different conditions: at room temperature $\left(23 \pm 1^{\circ} \mathrm{C}\right)$; refrigerated at $4 \pm 1^{\circ} \mathrm{C}$ and immediately photoactivated after removal from the refrigerator; and, refrigerated at $4 \pm 1{ }^{\circ} \mathrm{C}$ and photoactivated after a bench time of 15 min at room temperature. Measurements were made immediately after polymerization and after 7 days of storage. The hypotheses tested were that there are no differences in the mean Knoop hardness values of the composite resins regardless of the polymerization conditions or storage time before testing.

\section{MATERIAL AND METHODS}

Two commercially available composite resins were tested in this study: a hybrid composite (Charisma

Table 1. Tested materials.

\begin{tabular}{|c|c|c|c|c|c|c|}
\hline $\begin{array}{l}\text { Composite } \\
\text { resin }\end{array}$ & $\begin{array}{c}\text { Organic } \\
\text { matrix }\end{array}$ & Filler type and size & $\begin{array}{c}\text { Mean } \\
\text { filler size }\end{array}$ & $\begin{array}{c}\text { Filler } \\
\text { content } \\
(\mathrm{vol})\end{array}$ & Shade & Batch \\
\hline Charisma & $\begin{array}{l}\text { Bis-GMA } \\
\text { TEGDMA }\end{array}$ & $\begin{array}{l}\text { Barium aluminum } \\
\text { fluoride glass }(0.02- \\
0.07 \mu \mathrm{m}), \text { highly } \\
\text { dispersed silica } \\
(0.02-2 \mu \mathrm{m})\end{array}$ & $0.7 \mu \mathrm{m}$ & $64 \%$ & $\mathrm{~A} 2$ & 010093 \\
\hline $\begin{array}{c}\text { Durafill } \\
\text { VS }\end{array}$ & $\begin{array}{c}\text { Bis-GMA } \\
\text { UDMA } \\
\text { TEGDMA }\end{array}$ & $\begin{array}{c}\text { Pre-polymerized } \\
\text { particles }(10-20 \mu \mathrm{m}), \\
\text { highly dispersed silica } \\
(0.02-0.07 \mu \mathrm{m}) .\end{array}$ & $0.04 \mu \mathrm{m}$ & $40 \%$ & $\mathrm{~A} 2$ & 010149 \\
\hline
\end{tabular}

Source: Manufacturer.
(C); Heraeus Kulzer GmbH \& Co., Hanau, German) and a microfilled composite (Durafill VS (D); Heraeus Kulzer GmbH \& Co.) (Table 1). The Knoop hardness test was carried out to determine the surface hardness of the composite resins when submitted to different temperatures prior to polymerization.

For the control groups (immediate and 7 days) for both materials (C and D), the composite resin tubes were kept at $23 \pm 1{ }^{\circ} \mathrm{C}$ and a relative humidity of $50 \pm 5 \%$ up to the specimens preparation. For the other groups (refrigerated material), the composite resins were cooled to $4 \pm 1^{\circ} \mathrm{C}$ for $24 \mathrm{~h}$ before preparing the specimens; after this time the composite resin was removed from the tubes, placed at the mold and polymerized after different bench time at room temperature (Table 2).

In all groups, the temperature of the composite resin paste was verified before the polymerization with a digital multimeter (ET 2210; Minipa, São Paulo, SP, Brazil). The composite resins at room temperature $\left(23^{\circ} \mathrm{C}\right)$ took $15 \mathrm{~min}$ to reach $4^{\circ} \mathrm{C}$ when placed inside the refrigerator. When started at $4^{\circ} \mathrm{C}$, it was necessary the same 15 min out of the refrigerator for the resin paste to reach room temperature again. The same operator prepared all specimens and the 6 groups were divided as shown in Table 2.

For all groups cylindrical specimens were fabricated using a split stainless steel mold with a $4 \mathrm{~mm}$ diameter and $2 \mathrm{~mm}$ depth. A Mylar matrix was pressed against the composite resin surface using a $1 \mathrm{~mm}$ glass slide in order to obtain a smooth and flat surface. Visible light-activation was accomplished with a quartztungsten-halogen light-curing unit (Optilux VCL 501; Demetron/Kerr, Danbury, CT, USA) with irradiance of 490 $\mathrm{mW} / \mathrm{cm}^{2}$, as measured with a curing radiometer. The activation time was $20 \mathrm{~s}$, as recommended by the manufacturer. The energy density emitted was calculated by multiplying the irradiance by the emission time. Therefore, all specimens were exposed to an energy density of $9.8 \mathrm{~J} / \mathrm{cm}^{2}$.

After removing the specimens from the mold, the top was distinguished from the bottom and a line was draw at 
the center of each top and bottom surface. This provided one hemi-surface for immediate hardness testing and another for testing after 7 days. A microhardness tester (HVS 1000; NDT Instrument Co, Beijing, China) was used with a load of $50 \mathrm{~g}$ applied for $15 \mathrm{~s}$. Each specimen was tested immediately after polymerization and after a 7 -day storage in water at $23 \pm 1{ }^{\circ} \mathrm{C}$. Seven indentations were made on the top and 7 indentations were made on the bottom of each specimen at each period. The distance between each indentation was $\geq 4$ larger diagonals of the indenter (4D). This precaution was taken to prevent areas of plastic deformation produced by neighboring indentations from altering the hardness values (Fig. 1). The larger diagonal was measured with an optical microscope (Olympus BX 51; Olympus Corp, Tokyo, Japan) at 50-fold magnification, and using an image-analysis software (Image-Pro Express 5.0; MediaCybernetics Inc, Silver Spring, MD, USA). The values (in $\mu \mathrm{m}$ ) were converted into Knoop hardness number values using the following equation:

Table 2. Group description by composite and temperature.

\begin{tabular}{|c|c|c|}
\hline $\begin{array}{l}\text { Groups } \\
(n=20)\end{array}$ & Description & $\begin{array}{l}\text { Temperature } \\
\text { and humidity at } \\
\text { photoactivation }\end{array}$ \\
\hline $\begin{array}{l}\mathrm{C}_{\mathrm{AI}} / \mathrm{C}_{\mathrm{A} 7 \mathrm{~d}} \\
\mathrm{D}_{\mathrm{AI}} / \mathrm{D}_{\mathrm{A} 7 \mathrm{~d}}\end{array}$ & $\begin{array}{l}\text { Composite resins ( } \mathrm{C} \text { and } \\
\mathrm{D}) \text { polymerized at room } \\
\text { temperature }\end{array}$ & $23 \pm 1^{\circ} \mathrm{C} / 50 \pm 5 \%$ \\
\hline $\begin{array}{l}\mathrm{C}_{0 I} / \mathrm{C}_{07 d} \\
\mathrm{D}_{0 I} / \mathrm{D}_{07 d}\end{array}$ & $\begin{array}{c}\text { Composite resins }(\mathrm{C} \\
\text { and } \mathrm{D}) \text { polymerized } \\
\text { immediately after removal } \\
\text { refrigeration }\end{array}$ & $4 \pm 1^{\circ} \mathrm{C} / 50 \pm 5 \%$ \\
\hline $\begin{array}{l}\mathrm{C}_{15 I} / \mathrm{C}_{157 d} \\
\mathrm{D}_{15 I} / \mathrm{D}_{157 d}\end{array}$ & $\begin{array}{c}\text { Composite resins } \\
(\mathrm{C} \text { and } \mathrm{D}) \text { removed } \\
\text { from refrigeration and } \\
\text { polymerized after } 15-\mathrm{min} \\
\text { bench time. }\end{array}$ & $23 \pm 1^{\circ} \mathrm{C} / 50 \pm 5 \%$ \\
\hline
\end{tabular}

The legends $\left(\mathrm{C}_{\mathrm{A}}, \mathrm{C}_{0}, \mathrm{C}_{15}, \mathrm{D}_{\mathrm{A}}, \mathrm{D}_{0}\right.$ and $\left.\mathrm{D}_{15}\right)$ of discriminated groups, are valid from tables 2 to 4 . As well as legends $\left(A, 0\right.$ and $\left.{ }_{15}\right)$, that refere to composites that were photoactivated, respectively: at room temperature $\left(23 \pm 1^{\circ} \mathrm{C}\right)$ and at refrigerated temperature $\left(4 \pm 1^{\circ} \mathrm{C}\right)$ with a bench time of $0 \mathrm{~min}$ and $15 \mathrm{~min}$ at room temperature before polymerization. The legends $\left.{ }_{I}\right)$ and $\left.{ }_{7 d}\right)$ refer to the specimens tested immediately after polymerization and after storage for 7 days in the dark with relative humidity.
$K H N=\frac{14229 \times P}{d^{2}}$

Where:

$\mathrm{P}=$ applied load, in kgf;

$\mathrm{d}=$ larger diagonal, in $\mu \mathrm{m}$;

$\mathrm{KHN}=$ Knoop Hardness Number, in $\mathrm{kgf} / \mathrm{mm}^{2}$.

The average of the 7 indentations was calculated and this value was used as the KHN for each specimen $(n=20)$. Values were obtained from the top and bottom surfaces for each group, and the the bottom/top ratio $(\mathrm{B} / \mathrm{T})$ was determined.

The data were analyzed by multiple-way analysis of variance. When statistical differences were verified between the treatments, the means were individually analyzed with Tukey's HSD test at 5\% significance level.

\section{RESULTS}

The hardness values for the top surface of groups $\mathrm{C}_{\mathrm{AI}}$ and $\mathrm{C}_{15 I}$ did not differ significantly from each other ( $\mathrm{p}>0.05) . \mathrm{C}_{15 I}$ did not differ from $\mathrm{C}_{0 I}(\mathrm{p}>0.05)$, but $\mathrm{C}_{0 I}$ was significantly lower than $\mathrm{C}_{\mathrm{A} I}(\mathrm{p}<0.05)$. For the bottom surfaces, $\mathrm{C}_{0 I}$ and $\mathrm{C}_{15 I}$ showed lower mean values when compared to $\mathrm{C}_{\mathrm{A} I}(\mathrm{p}<0.05)$. The mean values for $\mathrm{C}_{\mathrm{A} 7 d}$, $\mathrm{C}_{07 d}$ and $\mathrm{C}_{157 d}$ did not differ significantly for either the top or the bottom surfaces $(p<0.05)$. After storage, no

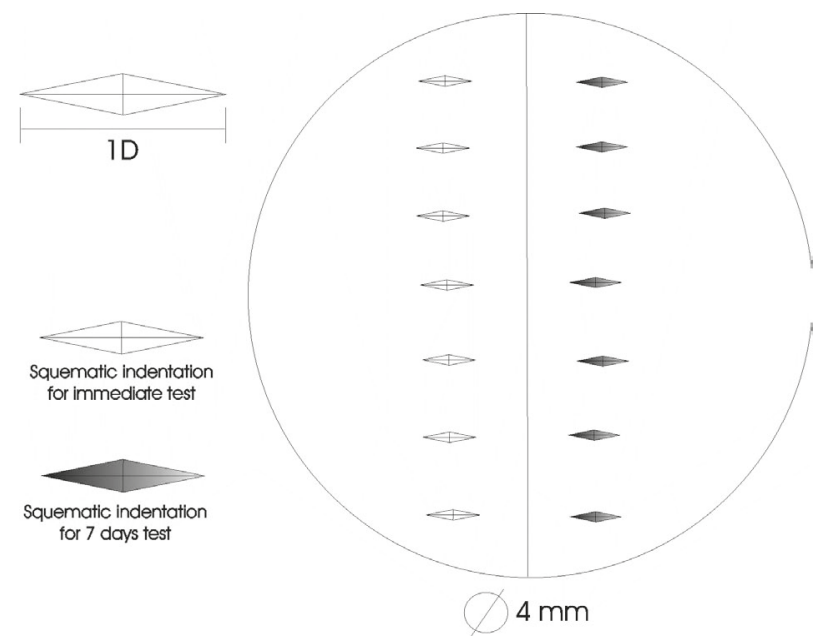

Figure 1. Schematic illustration of the Knoop hardness indentations. 
significant reduction in hardness was observed at the top and at the bottom surfaces of $\mathrm{C}_{0}$ (Table 3 ).

For D at the top surface, there were no statistically significant differences between the mean values for $\mathrm{D}_{\mathrm{AI}}$ and $\mathrm{D}_{15 I}(\mathrm{p}>0.05)$. $\mathrm{D}_{15 I}$ did not differ from $\mathrm{D}_{0 I}$ ( $\mathrm{p}>0.05$ ), but $\mathrm{D}_{0 I}$ yielded statistically lower mean values than $\mathrm{D}_{\mathrm{A} F}$. $(\mathrm{p}<0.05)$. Still at the top surface, microfill resin composite had also showed no statistically significance difference $(\mathrm{p}<0.05)$ between $\mathrm{D}_{\mathrm{A} 7 d}$ and $\mathrm{D}_{157 d}$. $\mathrm{D}_{07 d}$ showed higher hardness values when compared to both groups. After storage, significant reductions $(\mathrm{p}<0.05)$ in hardness of the top and the bottom surfaces were observed when comparing immediate and 7-day tests within the groups (Table 4).

The $\mathrm{B} / \mathrm{T}$ ratio did not present statistically significant differences with the tested temperatures between the immediate and the 7-day tests for $\mathrm{C}(\mathrm{p}>0.05)$. However, statistically significant differences $(p<0.05)$ were observed for $\mathrm{D}$, which presented lower values after 7 days of storage, though without significant differences between the tested temperatures $(p>0.05)$.

\section{DISCUSSION}

The results suggest influence of refrigeration on Knoop hardness values for the hybrid (C) and microfilled (D) composite resins tested in this study.

Both resins presented changes in the hardness

Table 3. Mean Knoop hardness number (KHN) and standard deviations (sd) for the composite Charisma tested at the top and bottom surfaces, immediately after polymerization and after 7 days of water storage.

\begin{tabular}{cccc}
\hline & $\mathrm{C}_{\mathrm{A}}$ & $\mathrm{C}_{0}$ & $\mathrm{C}_{15}$ \\
\hline Top $_{I}$ & $33.24(5.35) \mathrm{aA}$ & $30.46(3.57) \mathrm{bA}$ & $31.88(3.97) \mathrm{abA}$ \\
Top $_{7 d}$ & $28.65(4.41) \mathrm{aB}$ & $29.79(5.21) \mathrm{aA}$ & $28.41(4.73) \mathrm{aB}$ \\
& & & \\
Bottom $_{I}$ & $17.60(4.29) \mathrm{aC}$ & $15.46(3.31) \mathrm{bC}$ & $16.10(3.15) \mathrm{bC}$ \\
& & & \\
Bottom $_{7 d}$ & $14.51(3.16) \mathrm{aD}$ & $14.99(4.77) \mathrm{aC}$ & $14.49(2.94) \mathrm{aD}$ \\
\hline
\end{tabular}

${ }_{I}=$ Immediate ${ }_{7 d}=7$ days; Means followed by the same lowercase letters in rows and uppercase letters in columns indicate no statistically significant difference at the $95 \%$ confidence level (Tukey's test, $\mathrm{p}>0.05$ ). values verified right after the polymerization $\left.{ }_{I}\right)$ between the specimens prepared at room temperature $(\mathrm{A})$ and just after removal of the resin from refrigeration at $4^{\circ} \mathrm{C}\left({ }_{0}\right)$.

The strong influence of temperature in the polymerization process of the composite resins found by Daronch et al. (9), who showed an increase in the degree of conversion at a $60^{\circ} \mathrm{C}$ and a decrease at $3^{\circ} \mathrm{C}$, does not seem to apply when using hardness testing and temperatures of $4 \pm 1^{\circ} \mathrm{C}$ and $23 \pm 1^{\circ} \mathrm{C}$.

With a bench time of $15 \mathrm{~min}$ after removal from the refrigerator, the temperature of both composites was $23^{\circ} \mathrm{C}$. The statistically similar top surface hardness values for the groups tested at room temperature and 15 min after removal from the refrigerator was an expected finding. The hardness on the top surface was higher than the hardness on the bottom at all time periods, indicating difficulty in polymerizing the bottom surface. This can be partially attributed to the fact that proximity of the top surfaces to the light source and their receiving a higher energy density $(5,6,13,14)$.

The temperature increase caused by halogen light-curing units, as reported by Soh et al. (13), might have helped the polymerization kinetics at the top surface by heating (4). However, the temperature increase may not have been enough to aid the polymerization at the bottom surface due to the isolating characteristics of the composite resin and the great distance from the light source $(15,16)$.

Table 4. Mean Knoop hardness number (KHN) and standard deviations (sd) for the composite Durafill VS tested at the top and bottom surfaces, immediately after polymerization and after 7 days of water storage.

\begin{tabular}{cccc}
\hline & $\mathrm{D}_{\mathrm{A}}$ & $\mathrm{D}_{0}$ & $\mathrm{D}_{15}$ \\
\hline $\mathrm{Top}_{I}$ & $19.16(2.87) \mathrm{aA}$ & $18.02(1.84) \mathrm{bA}$ & $18.58(2.61) \mathrm{abA}$ \\
Top $_{7 d}$ & $15.42(2.15) \mathrm{aB}$ & $16.32(3.0) \mathrm{bB}$ & $15.07(3.09) \mathrm{aB}$ \\
Bottom $_{I}$ & $9.43(1.65) \mathrm{aC}$ & $9.34(2.67) \mathrm{aC}$ & $9.21(3.98) \mathrm{aC}$ \\
& & & \\
Bottom $_{7 d}$ & $7.25(1.74) \mathrm{aD}$ & $7.61(2.53) \mathrm{aD}$ & $6.83(1.80) \mathrm{aD}$ \\
\hline
\end{tabular}

${ }_{\Gamma}=$ Immediate; ${ }_{7 d}=7$ days; Means followed by the same lowercase letters in rows and uppercase letters in columns indicate no statistically significant difference at the $95 \%$ confidence level (Tukey's test, $\mathrm{p}>0.05$ ). 
Studies have reported that the hardness values at the bottom surface should be between 80 and $90 \%$ of the hardness at the top surfaces in order to indicate a proper polymerization $(11,12,17)$. In this study, the exposure duration recommended by the manufacturer resulted in bottom-to-top-surface Knoop hardness ratios between 47 to $54 \%$ for the tested resins. This is in agreement with the findings of Cohen et al. (18), who reported the need for exposing the specimens from a 5 - to 20 -fold longer time than that indicated by the manufacturer to achieve $80 \%$ bottom-surface hardness with respect to the top. Caldas et al. (6) have also suggested using a longer curing time, in order to increase the energy density at the bottom of the layer and increase the degree of conversion.

Ideally, the manufacturers should inform the needed energy density and not only the curing time for an appropriate conversion at the bottom of the recommended maximum layer (19). The $\mathrm{B} / \mathrm{T}$ ratio was not altered for $\mathrm{C}$ in the tests carried out immediately and 7 days after polymerization. However, for $\mathrm{D}$, this ratio decreased after 7 days, which suggests that although the values at the top and bottom have decreased with water storage, the bottom presented a more accentuated decrease. This could be explained by the bottom being less polymerized and thus, more susceptible to the influence of water during storage.

After 7 days for $\mathrm{C}$, in both tested surfaces, the differences seen with the refrigerated material within groups were not observed, thus accepting the null hypothesis. A possible explanation could be that the initial difference was impacted by residual stress resulting from polymerization due to the effect of the temperature generated by the curing unit, mainly on the composite at the room temperature. Stress relaxation may have contributed to the hardness values being not statistically different for the 3 tested temperature conditions after 7 days of storage.

However, $\mathrm{D}_{0}$ showed the smallest decrease in hardness at the top surface after 7 days, differing from the others and rejecting the null hypothesis.

The microfilled resin composite with a filler load of $40 \mathrm{vol} \%$ and hence more resin matrix than the hybrid composite was even more sensitive to the phenomenon of residual stress and posterior relaxation at the top surface. The composite resin polymerized at the room temperature presented lower hardness mean values than the resin polymerized at $4^{\circ} \mathrm{C}$ after 7 days. A possible explanation would be that the hardness at the top surface of both refrigerated resin composites was less affected by the temperature of the curing unit, generating less stress during its polymerization. It may be speculated that faster polymerization occurred at room temperature was influenced by the heat generated by the halogen lamp, which led to the entrapment of low molecular weight monomers among long polymer chains, hindering the formation of the polymer network. Therefore, hardness measurement immediately after the testing would not express the actual hardness of the material because the residual stress generated during the polymerization process accounts for reaching increased values.

These results suggest that the refrigeration allowed a behavior of the composite resin similar to the "soft start polymerization method" because, the low temperature could have proportioned less monomer mobility, decreasing the reaction velocity and providing an extension of the pre-gel phase without decreasing hardness values (20).

Despite the promising results from this preliminary study, pointing to a decrease in the stress generated during polymerization with refrigerated composite resins, further research has been conducted keeping the molds at $37^{\circ} \mathrm{C}$ to simulate the intraoral conditions in a better manner, although the insulating properties of composites is known.

According to the results, and within the limitations of this in vitro study, it may be concluded that for the hybrid composite resin, only the immediate hardness values were impacted by the temperature at the top and bottom surfaces. After 7 days for C, no statistically significant difference was observed regardless of the temperature. For $\mathrm{D}_{\mathrm{A} I}$ the top hardness value was higher than $\mathrm{D}_{0 I}$. However, the $\mathrm{D}_{0}$ hardness value was higher than the $\mathrm{D}_{\mathrm{A}}$ values after 7 days. The $\mathrm{B} / \mathrm{T}$ ratio did not differ for the hybrid composite resin among the tested groups. The $\mathrm{B} / \mathrm{T}$ ratio did not differ for the microfilled composite resin with the different temperatures, but decreased after 7 days of storage.

\section{RESUMO}

O objetivo do presente estudo in vitro foi avaliar a dureza Knoop das resinas compostas, uma resina híbrida (Charisma - C) e uma de micropartículas (Durafill VS - D) quando polimerizadas à temperatura ambiente $\left({ }_{\mathrm{A}}\right)\left(23 \pm 1^{\circ} \mathrm{C}\right)$; refrigeradas $\left(4 \pm 1^{\circ} \mathrm{C}\right) \mathrm{e}$ fotoativadas imediatamente após a remoção do refrigerador $(0)$; e refrigeradas $\left(4 \pm 1^{\circ} \mathrm{C}\right)$, com tempo de espera de $15 \mathrm{~min}$ após a remoção do refrigerador para fotoativação $\left({ }_{15}\right)$. Cento e vinte corpos-de-prova com $4 \mathrm{~mm}$ de diâmetro por $2 \mathrm{~mm}$ de altura 
foram confeccionados em uma matriz de aço inoxidável. Cada corpo-de-prova foi testado imediatamente após a fotoativação $\left.{ }_{I}\right)$ e, após 7 dias de armazenamento $\left.{ }_{7 d}\right)$ em ambiente escuro com umidade relativa a $100 \%$, à temperatura do ambiente $(23 \pm$ $\left.1^{\circ} \mathrm{C}\right)$. Quando testada imediatamente após a polimerização, na superfície de topo $\mathrm{C}_{\mathrm{A} I}$ foi estatisticamente semelhante à $\mathrm{C}_{15 I}$ e $\mathrm{D}_{\mathrm{A} I}$ à $\mathrm{D}_{15 \text { I }}$. Na base, a resina composta $\mathrm{C}_{\mathrm{A} I}$, teve maiores valores de dureza quando comparados à $\mathrm{C}_{0 I} \mathrm{e} \mathrm{C}_{15 I}$. Os grupos do material $\mathrm{D}$ não mostraram diferenças significantes com relação ao efeito da refrigeração na base. Sete dias após, os valores de dureza Knoop caíram tanto para $\mathrm{C}_{7 d}$ quanto para $\mathrm{D}_{7 d}$ com exceção de $\mathrm{C}_{07 d}$ que não diferiu de $\mathrm{C}_{07 d}$ nas diferentes superfícies, e $\mathrm{D}_{07 d}$ que mostrou maiores valores de dureza no topo.

\section{ACKNOWLEDGEMENTS}

The authors would like to thank Heraeus Kulzer for supplying the composite resins and the Physics' Department of the Federal University of Parana, especially Professors Carlos Maurício Lepienski and Paulo César Soares Júnior for the technical and intellectual support during this research.

\section{REFERENCES}

1. Gerzina TM, Hume WR. Effect of dentin on release of TEGDMA from resin composite in vitro. J Oral Rehabil 1994;21:463-468.

2. Hansel C, Leyhausen G, Mai UE, Geursten W. Effects of various resin composite (co)monomers and extracts on two caries-associated micro-organisms in vitro. J Dent Res 1998;77:60-67.

3. Ferracane JL, Mitchem JC, Condon JR, Todd R. Wear and marginal breakdown of composites with various degrees of cure. J Dent Res 1997;76:1508-1516.

4. Lovell LG, Newmann SM, Bowman CN. The effects of light intensity, temperature, and comonomer composition on the polymerization behavior of dimethacrylate dental resins. J Dent Res 1999;78:1469-1476.

5. Feng L, Carvalho R, Suh BI. Insufficient cure under the condition of high irradiance and short irradiation time. Dent Mater 2009;25:283-289.

6. Caldas DB, Almeida JB, Correr-Sobrinho L, Sinhoreti MA, Consani S. Influence of curing tip distance on resin composite Knoop hardness number, using three different light curing units. Oper Dent 2003;28:315-320.
7. Kloosterboer JG, van de Hei GMM, Gossink RG, Dortant GCM. The effects of volume relaxation and thermal mobilization of trapped radicals on the final conversion of photopolymerized diacrylates. Pol Commun 1984;25:322-325.

8. Trujillo M, Newmann SM, Stansbury JW. Use of near-IR to monitor the influence of external heating on dental composite photopolymerization. Dent Mat 2004;20:766-777.

9. Daronch M, Rueggeberg FA, De Goes MF. Monomer conversion of pre-heated composite. J Dent Res 2005;84:663-667.

10. Borges GA, Spohr AM, Oliveira WJ, Correr-Sobrinho L, Correr AB, Borges LH. Braz Dent J 2006;17:186-190.

11. DeWald JP, Ferracane JL. A comparison of four modes of evaluating depth of cure of light-activated composites. J Dent Res 1987;66:727-730.

12. Bouschlicher MA, Rueggeberg FA, Wilson BM. Correlation of bottom-to-top surface microhardness and conversion ratios for a variety of resin composite compositions. Oper Dent 2004;29:698704.

13. Soh MS, Yap AUJ, Siow KS. The effectiveness of cure of LED and halogen curing lights at varying cavity depths. Oper Dent 2003;28:707-715.

14. Lindberg A, Peutzfeld A, van Dijken JWV. Effect of power density of curing unit, exposure duration, and light guide distance on composite depht of cure. Clin Oral Invest 2005;9:71-76.

15. Al-Qudah AA, Mitchell CA, Biagioni PA, Hussey DL. Thermographic investigation of contemporary resin-containing dental materials. J Dent 2005;33:593-602.

16. Stewardson DA, Shortall AC, Harrington E, Lumley PJ. Thermal changes and cure depths associated with a high intensity light activation unit. J Dent 2004;32:643-651.

17. Johnston WM, Leung RL, Fan PL. A mathematical model for postirradiation hardening of photoactivated composite resins. Dent Mat 1985;1:191-194.

18. Cohen ME, Leonard DL, Charlton DG, Roberts HW, Ragain JC. Statistical estimation of resin composite polymerization sufficiency using microhardness. Dent Mat 2004;20:158-166.

19. Obici AC, Sinhoreti MAC, Correr-Sobrinho L, de Goes, MF, Consani S. Evaluation of depth of cure and Knoop hardness in a dental composite photo-activated using different methods. Braz Dent J 2004;15:199-203.

20. Dall'Magro E, Sinhoreti MAC, Correr AB, Correr-Sobrinho L, Consani S, Puppin-Rontani RM. Effect of different initial light intensity by the soft-start photoactivation on the bond strength and knoop hardness of a dental composite. Braz Dent J 2007;18:107112. 